\title{
Effects of environmental light colors on the larviculture of the Amazon River prawn Macrobrachium amazonicum
}

\author{
Argemiro Midonês Bastos ${ }^{1} \cdot$ Jô Farias Lima ${ }^{2} \cdot$ Marcos Tavares-Dias $^{1,2}$ (D)
}

Received: 3 March 2019 / Accepted: 30 May 2019 / Published online: 8 July 2019

(C) Springer Nature Switzerland AG 2019

\begin{abstract}
This study aimed to investigate the effects of red, yellow, green, violet, blue, and white light in Macrobrachium amazonicum larviculture. The trials were composed of six treatments (i.e., colors red, yellow, green, blue, violet, and white light in tanks) with four replicates each. Transparent tanks of $1 \mathrm{~L}$ of water, 10 salinity, and 2400 newly hatched larvae were used in trials. The larvae were fed Artemia salina nauplii and complemented with commercial shrimp feed daily. The light color affected the temperature, $\mathrm{pH}$, and dissolved oxygen in the water culture and nauplii consumption, survival, and productivity of M. amazonicum. In the tanks with red light, the mean temperature was lower, while the oxygen and $\mathrm{pH}$ levels were higher than those with other colors. The mean consumption of $A$. salina nauplii was $15 \%$ higher by M. amazonicum in tanks with blue and violet light than red light. No difference in larval development was observed; however, larvae cultured under white light completed the larval cycle four days earlier than those cultured under red light. The productivity of larvae cultivated under white and violet light was $45 \%$ greater than larvae cultured under red light, and the survival was $>75 \%$. Results indicated that M. amazonicum larval cultivation should be performed in tanks under bright light, preferably white, since other colors may negatively affect the larval development.
\end{abstract}

Keywords Larval cycle $\cdot$ Light $\cdot$ Macrobrachium amazonicum $\cdot$ Productivity $\cdot$ Survival

\section{Introduction}

Light comprises a group of environmental factors, including photoperiod, color spectrum, and intensity, which may influence several behaviors and physiological responses with

Marcos Tavares-Dias

marcos.tavares@embrapa.br

1 Pós-Graduação Rede de Biodiversidade e Biotecnologia da Amazônia (PPG-BIONORTE),

Universidade Federal do Amapá, Macapá, AP, Brazil

2 Embrapa Amapá, Macapá, AP, Brazil 
considerable effects on growth, survival, sexual maturity, regeneration, and even sexual ratio of aquatic organisms (Giri et al. 2002; Hoang et al. 2003). The characteristics of light are incredibly variable in natural environments (Meyer-Rochow 2001). In aquaculture light, can to be a critical environmental parameter, especially in intensive farming, which uses tanks under covered housing and relies on artificial light (Valenti et al. 2010; Guo et al. 2011; Guo et al. 2012; Utne-Palm et al. 2018). Hence, for crustaceans, several studies have investigated the light conditions and found significant differences in their behavior, nutrition, molting frequency, and growth of animals (Guo et al. 2012; Guo et al. 2013; Jaski et al. 2014).

Various studies have reported that the periodic light color and rhythmic light color fluctuations have effects on the molting frequency, growth, and feeding rate in larvae of shrimps (Dendrobranchiuata) and prawns (Pleyocemata) (Guo et al. 2011; Araújo and Valenti 2011; Guo et al. 2012; Guo et al. 2013; Kawamura et al. 2018) and consequently in production and productivity.

Light intensity is directly related to the ability to identify food in the environment, which has been shown in the of larval development of Macrobrachium rosenbergii, where the random opportunity to find food is the most vital factor in feeding behavior (Araújo and Valenti 2011), as in Amazon River prawn Macrobrachium amazonicum. In addition, color also plays an essential role in the eating habit of the shrimps in aquaculture (Kawamura et al. 2018) since each color receptor responds to different spectral color bands (Scarinci and Marineli 2014). The relationship between light color and the life cycle of prawns and shrimps has been disregarded as a variable that may affect their cultivation (You et al. 2006; Zhang et al. 2006; Guo et al. 2011, 2012). However, studies have been demonstrated that periodic fluctuation of light from blue to green improves the growth of farmed Litopenaeus vannamei (Guo et al. 2011, 2012). Therefore, efficient growth is important for the commercial production of shrimps and prawns since the aim of production is to improve the costbenefit relationship in growth (Guo et al. 2011, 2012).

The larviculture is a crucial phase in the production of Amazon River prawn, the most important freshwater prawn for Brazilian and Amazonian aquaculture, and this has suitable zootechnical characteristics, such as fast growth and robustness (Maciel and Valenti 2009; Lima and Santos 2014). The present study aimed to assess the effect of the light color in cultivation tanks on the development, productivity, and survival of M. amazonicum larvae. In this study, we tested the hypothesis that the constant use of bright light could increase the productivity and survival of M. amazonicum larvae.

\section{Materials and methods}

\section{Animals and experimental conditions}

This experiment with $M$. amazonicum was conducted over 28 days at the Larviculture

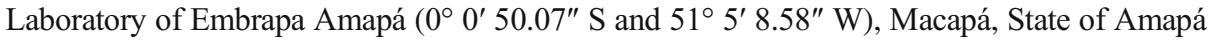
(Brazil). A total of 2400 newly hatched larvae were collected from females collected in the Igarapé Fortaleza basin ( $0^{\circ} 1^{\prime} 35.75^{\prime \prime} \mathrm{S}$ and $\left.51^{\circ} 8^{\prime} 16.40^{\prime \prime} \mathrm{W}\right)$.

The trial comprised six treatments (red, yellow, green, blue, violet, and white light), each with four replicates using newly hatched larvae of M. amazonicum. Four replicates for treatment and transparent boxes containing $1 \mathrm{~L}$ of water in 10 salinity with 100 larvae by boxes were used. Internally, the tanks were illuminated daily for $12 \mathrm{~h}$ using fluorescent monochromatic (15 W) lamps (Empalux@) in the colors red (R), yellow (Y), green $(\mathrm{G})$, blue 
(B), violet (V), and white (W), positioned $70 \mathrm{~cm}$ above the bottom of the tanks. The frequency, photon energy, and light quantity for the colors used were measured using a Digital Lux Meter (Minipa ${ }^{\circledR}$, mod. MLM-1011, Houston, USA) and are in Table 1. The cares to prevent light intervention was carried out. The boxes of $1 \mathrm{~L}$ were put inside black tanks of $70 \mathrm{~L}$ and covered with black woven fabric to isolate them from external light. During the experimental period, constant aeration was maintained in each box.

Water temperature, $\mathrm{pH}$, and dissolved oxygen were measured daily using a multiparameter analyzer (Horiba®, mod. U-52G, Tokyo, Japan), followed by cleaning to remove uneaten food and dead larvae in each tank. The total ammonia levels were measured every 3 days using an ammonia measurement photometer (Hanna ${ }^{\circledR}$ mod. HI 96715C, Romania). In the experiment tanks with larvae of M. amazonicum was a daily replacement of $50 \%$ water volume.

\section{Feeding and larval conditions}

The larvae were fed in the morning (8:00 AM) from the second day of cultivation with newly enclosed nauplii of Artemia salina. The nauplii consumption was estimated daily through the methodology described by Tayamen and Brown (1999). After stage V, larval feeding was complemented with commercial shrimp feed at 4:00 PM. At the end of the experiment, larvae and post-larvae of each repetition were counted to determine survival (S) and productivity $(\mathrm{P})$ rates, using the following equations:

$$
\begin{gathered}
S(\%)=\left(N_{T} / N_{0}\right) \times 100 \\
P=\left(N_{T} / L\right)
\end{gathered}
$$

where $S=$ the survival rate, $N_{T}=$ the number of survival larvae and post-larvae, $N_{0}=$ the initial number of larvae, $P=$ the productivity, and $\mathrm{L}=$ the tank volume $(\mathrm{L})$.

Every 2 days, 10 larvae of each repetition were randomly collected and analyzed to estimate the larval stage index (LSI) based on the determination of mean weight (Manzi et al. 1977). Also, the larval condition index (LCI) was estimated following the recommendations of Tayamen and Brown (1999). The experiment ended when $80 \%$ of post-larvae were obtained in all treatments.

\section{Statistical analysis}

Previously, normality and homoscedasticity were tested using the Shapiro-Wilk and Bartlett tests, respectively. Data with a non-normal distribution were tested using the Kruskal-Wallis followed by

Table 1 Frequency band and energy of each photon, and quantity of light for the colors used in cultivation tanks

\begin{tabular}{llll}
\hline Light color & Frequency $\left(10^{14} \mathrm{~Hz}\right)$ & Energy $\left(10^{-19} \mathrm{~J}\right)$ & Light quantity (lux) \\
\hline Red & $4.30-4.80$ & $2.85-3.18$ & 45 \\
Yellow & $5.10-5.40$ & $3.38-3.58$ & 200 \\
Green & $5.40-5.80$ & $3.58-4.00$ & 225 \\
Blue & $6.10-6.70$ & $4.00-4.45$ & 110 \\
Violet & $6.70-7.50$ & $4.45-4.97$ & 5 \\
White & - & - & 400 \\
\hline
\end{tabular}


Dunn's test for comparison between medians. Data with normal distribution were tested using ANOVA followed by the Tukey for comparison between means. The Spearman correlation coefficient $(r s)$ was used to investigate the possible correlations of light color with survival (Zar 2010). All these analyses were conducted using the software R (R Core Team 2015).

\section{Results}

Physical and chemical parameters were monitored during the 28 trial days; in the red-light tanks, the mean temperature was lower, and $\mathrm{pH}$ and dissolved oxygen were higher than the remaining tanks. The ammonia levels were not affected (Fig. 1).

The consumption of $A$. salina nauplii was affected $(p<0.05)$ by the color of light in the tanks during the initial phase of larviculture, i.e., until the sixth day. The consumption was $15 \%$ greater in M. amazonicum larvae maintained under blue (2708 nauplii/larvae) and violet (2640 nauplii/larvae) than red (2322 nauplii/larvae) light. Consumption oscillated in the first days for all types of light until day 14 of the trial, when the larvae reached stage V. From when the commercial feed was used to complement the daily feeding of larvae, stability in nauplii consumption was obtained at approximately 100 nauplii/larvae per treatment, until the complete larval metamorphosis (Table 2).

No significant difference $(p>0.05)$ in LSI according to light color was observed, but larvae under white light completed their larval development cycle 4 days earlier than those under red light. After day 8 of the experiment, stage V larvae were identified only in tanks with white and violet light (Table 3). For larvae grown under red light, the larval period duration was the highest among all lights under analysis, with a mean of three days in each stage. The first postlarvae were identified in white and violet light in day 18 of the experiment.

Significant differences $(p<0.01)$ were observed in the LCI concerning light color used in the tanks. For the M. amazonicum larvae under red or green light, the LCI was 1.52 and 1.65 , respectively, in the first 10 days of the experiment. The best indexes were observed in larvae cultivated with white $(\mathrm{LCI}=1.95)$ and violet $(\mathrm{LCI}=1.88)$ light. Larval survival was also affected $(p>0.01)$ by the light color used in the cultivation tanks with the greatest survival in tanks under green, blue, violet, and white light. The larvae maintained in tanks under yellow and red light presented the lowest survival (Fig. 2). The light color used in tanks affected $(p<$ $0.01)$ the productivity $(P)$ of $M$. amazonicum larvae, which was higher in tanks under white $(P$ $\left.=75 \pm 4.2 \mathrm{~L}^{-1}\right)$ and violet $\left(P=64 \pm 4.8 \mathrm{~L}^{-1}\right)$ than in red $\left(P=30 \pm 3.1 \mathrm{~L}^{-1}\right)$, yellow $(P=36 \pm .7$ $\left.\mathrm{L}^{-1}\right)$, green $\left(P=42 \pm 1.8 \mathrm{~L}^{-1}\right)$, and blue $\left(P=56 \pm 2.3 \mathrm{~L}^{-1}\right)$ light.

\section{Discussion}

In the larviculture of M. amazonicum using green, blue, red, yellow, violet, and white light due to daily replacement of water volume, there was an increase in temperature in the tanks under green light and a decrease of $\mathrm{pH}$ and dissolved oxygen levels than that in tanks under red, blue, violet, and white light. However, ammonia levels were not affected. This increase of temperature is associated with the energy that is transferred to the water by radiation photons of each color, since the higher the frequency, the greater the photon energy (Bohren et al. 2007). Therefore, this energy may be partially converted to thermal energy transferred to water mass in tanks by red light in the present study. The reduction of $\mathrm{pH}$ and dissolved oxygen level was 

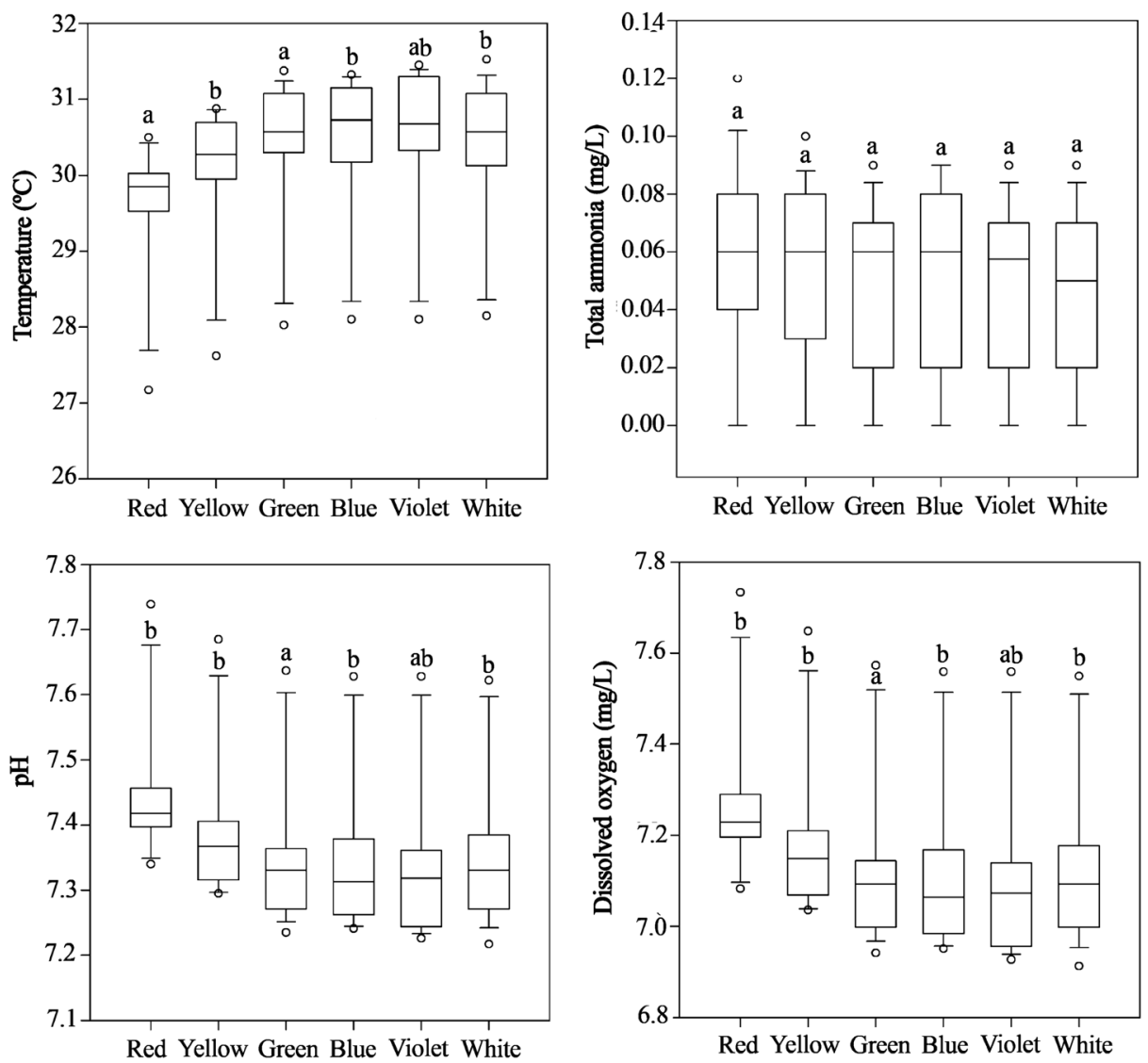

Fig. 1 Temperature, $\mathrm{pH}$, dissolved oxygen, and total ammonia during the 28 days of larviculture of Macrobrachium amazonicum under different light colors (box plots represent medians, interquartile ranges, minimum-maximum ranges, and outliers). Median values followed by the same letters, in the same column, do not differ among themselves by the Dunn test

the result of the temperature increase in the cultivation tanks under green light. However, even with this variation in temperature, $\mathrm{pH}$, and oxygen in cultivation tanks, the levels found were like those described in previous studies (Araújo and Valenti 2011; Maciel and Valenti 2014) on M. amazonicum larviculture.

The main light and dark receptors in crustaceans are compound eyes, frontal organs, intracerebral ocelli, and caudal photoreceptors, but some crustaceans also have photoreceptors (Meyer-Rochow 2001; Cronin et al. 2017). Shrimp species that live in natural waters move in different water layers with different light colors in the environment (Guo et al. 2011, 2012). Mechanism of eye functions of Macrobrachium species is still unknown; however, they are well adapted to their habitats owing to their visual ability, which is correlated with their natural behavior. The eye can function under low light conditions, but if the habitat is highly turbid, the organisms might face difficulties in feeding, mating, and migrating, since vision is fundamental in the predator-prey dynamic (Matsuda and Wilder 2014; Cronin et al. 2017). For M. amazonicum larvae from the present study, the color of light used in the cultivation 
Table 2 The number of Artemia salina nauplii consumed by Macrobrachium amazonicum larvae in tanks under different light colors for $12 \mathrm{~h}^{\text {day }}{ }^{-1}$

\begin{tabular}{|c|c|c|c|c|c|c|}
\hline \multirow[t]{2}{*}{ Days } & \multicolumn{6}{|c|}{ Light color of tanks } \\
\hline & Blue & Green & Red & Violet & Yellow & White \\
\hline 2 & $83 \pm 8^{\mathrm{aB}}$ & $85 \pm 16^{\mathrm{aB}}$ & $48 \pm 6^{\mathrm{fC}}$ & $118 \pm 4^{\mathrm{aA}}$ & $51 \pm 7 \mathrm{dC}$ & $68 \pm 12^{\mathrm{aBC}}$ \\
\hline 3 & $104 \pm 23^{\mathrm{aA}}$ & $83 \pm 12^{\mathrm{aABC}}$ & $58 \pm 5^{\mathrm{efC}}$ & $99 \pm 12^{\mathrm{aAB}}$ & $63 \pm 12^{\mathrm{cdBC}}$ & $94 \pm 20^{\mathrm{aABC}}$ \\
\hline 4 & $116 \pm 22^{\mathrm{aA}}$ & $83 \pm 9^{\mathrm{aAB}}$ & $61 \pm 3^{\mathrm{defB}}$ & $110 \pm 8^{\mathrm{aA}}$ & $64 \pm 8^{\mathrm{cdB}}$ & $111 \pm 23^{\mathrm{aA}}$ \\
\hline 5 & $103 \pm 17^{\mathrm{aA}}$ & $89 \pm 14^{\mathrm{aA}}$ & $66 \pm 10^{\text {cdefA }}$ & $98 \pm 12^{\mathrm{aA}}$ & $76 \pm 24^{\mathrm{bcdA}}$ & $87 \pm 7^{\mathrm{aA}}$ \\
\hline 6 & $79 \pm 8^{\mathrm{aB}}$ & $82 \pm 15^{\mathrm{aAB}}$ & $67 \pm 5^{\mathrm{cdefB}}$ & $115 \pm 16^{\mathrm{aA}}$ & $73 \pm 16^{\mathrm{bcdB}}$ & $91 \pm 14^{\mathrm{aAB}}$ \\
\hline 7 & $98 \pm 9^{\mathrm{aA}}$ & $100 \pm 2^{\mathrm{aA}}$ & $83 \pm 6^{\text {abcdeA }}$ & $103 \pm 18^{\mathrm{aA}}$ & $87 \pm 11^{\mathrm{abcdA}}$ & $98 \pm 7^{\mathrm{aA}}$ \\
\hline 8 & $100 \pm 18^{\mathrm{aA}}$ & $95 \pm 25^{\mathrm{aA}}$ & $91 \pm 12^{\mathrm{abcdA}}$ & $99 \pm 26^{\mathrm{aA}}$ & $104 \pm 24^{\mathrm{abcdA}}$ & $99 \pm 19^{\mathrm{aA}}$ \\
\hline 9 & $95 \pm 14^{\mathrm{aA}}$ & $76 \pm 4^{\mathrm{aA}}$ & $82 \pm 11^{\text {abcdeA }}$ & $86 \pm 21^{\mathrm{aA}}$ & $86 \pm 13^{\mathrm{abcdA}}$ & $102 \pm 13^{\mathrm{aA}}$ \\
\hline 10 & $102 \pm 15^{\mathrm{aA}}$ & $104 \pm 19^{\mathrm{aA}}$ & $96 \pm 7^{\mathrm{abcA}}$ & $87 \pm 5^{\mathrm{aA}}$ & $95 \pm 20^{\mathrm{abcdA}}$ & $92 \pm 19^{\mathrm{aA}}$ \\
\hline 11 & $114 \pm 23^{\mathrm{aA}}$ & $100 \pm 22^{\mathrm{aA}}$ & $97 \pm 7^{\mathrm{abcA}}$ & $92 \pm 18^{\mathrm{aA}}$ & $112 \pm 16^{\mathrm{abcA}}$ & $74 \pm 12^{\mathrm{aA}}$ \\
\hline 12 & $104 \pm 15^{\mathrm{aA}}$ & $96 \pm 19^{\mathrm{a} A}$ & $101 \pm 15^{\mathrm{abA}}$ & $122 \pm 13^{\mathrm{aA}}$ & $103 \pm 23^{\mathrm{abcdA}}$ & $93 \pm 10^{\mathrm{aA}}$ \\
\hline 13 & $110 \pm 18^{\mathrm{aA}}$ & $104 \pm 12^{\mathrm{aA}}$ & $115 \pm 12^{\mathrm{aA}}$ & $96 \pm 27^{\mathrm{aA}}$ & $130 \pm 23^{\mathrm{aA}}$ & $106 \pm 15^{\mathrm{aA}}$ \\
\hline 14 & $104 \pm 10^{\mathrm{aA}}$ & $91 \pm 21^{\mathrm{aA}}$ & $88 \pm 15^{\text {abcdeA }}$ & $91 \pm 10^{\mathrm{aA}}$ & $98 \pm 15^{\mathrm{abcdA}}$ & $103 \pm 8^{\mathrm{aA}}$ \\
\hline 15 & $102 \pm 19^{\mathrm{aA}}$ & $95 \pm 14^{\mathrm{aA}}$ & $88 \pm 12^{\text {abcdeA }}$ & $120 \pm 17^{\mathrm{aA}}$ & $91 \pm 15^{\mathrm{abcdA}}$ & $91 \pm 16^{\mathrm{aA}}$ \\
\hline 16 & $125 \pm 10^{\mathrm{aA}}$ & $95 \pm 18^{\mathrm{aA}}$ & $100 \pm 15^{\mathrm{abA}}$ & $86 \pm 15^{\mathrm{aA}}$ & $103 \pm 18^{\mathrm{abcd} A}$ & $90 \pm 20^{\mathrm{aA}}$ \\
\hline 17 & $97 \pm 27^{\mathrm{aA}}$ & $89 \pm 12^{\mathrm{aA}}$ & $87 \pm 13^{\text {abcdeA }}$ & $80 \pm 17^{\mathrm{aA}}$ & $95 \pm 20^{\mathrm{abcdA}}$ & $90 \pm 10^{\mathrm{aA}}$ \\
\hline 18 & $101 \pm 14^{\mathrm{aA}}$ & $98 \pm 6^{\mathrm{aA}}$ & $98 \pm 12^{\mathrm{abA}}$ & $91 \pm 15^{\mathrm{aA}}$ & $100 \pm 14^{\mathrm{abcd} A}$ & $99 \pm 20^{\mathrm{aA}}$ \\
\hline 19 & $90 \pm 16^{\mathrm{aAB}}$ & $79 \pm 5^{\mathrm{aB}}$ & $96 \pm 8^{\mathrm{abcAB}}$ & $113 \pm 16^{\mathrm{aAB}}$ & $117 \pm 16^{\mathrm{abA}}$ & $105 \pm 13^{\mathrm{aAB}}$ \\
\hline 20 & $97 \pm 11^{\mathrm{aA}}$ & $81 \pm 18^{\mathrm{aA}}$ & $86 \pm 15^{\text {abcdeA }}$ & $88 \pm 10^{\mathrm{aA}}$ & $91 \pm 21^{\mathrm{abcd} A}$ & $76 \pm 16^{\mathrm{aA}}$ \\
\hline 21 & $90 \pm 10^{\mathrm{aA}}$ & $75 \pm 9^{\mathrm{aA}}$ & $92 \pm 9^{\mathrm{abcd} A}$ & $87 \pm 23^{\mathrm{aA}}$ & $93 \pm 13^{\mathrm{abcd} A}$ & $98 \pm 17^{\mathrm{aA}}$ \\
\hline 22 & $92 \pm 10^{\mathrm{aA}}$ & $78 \pm 18^{\mathrm{aA}}$ & $91 \pm 11^{\mathrm{abcdA}}$ & $98 \pm 9^{\mathrm{aA}}$ & $98 \pm 17^{\mathrm{abcdA}}$ & $95 \pm 15^{\mathrm{aA}}$ \\
\hline 23 & $110 \pm 34^{\mathrm{aA}}$ & $89 \pm 18^{\mathrm{aA}}$ & $94 \pm 13^{\mathrm{abcA}}$ & $105 \pm 13^{\mathrm{aA}}$ & $102 \pm 16^{\mathrm{abcd} A}$ & $97 \pm 16^{\mathrm{aA}}$ \\
\hline 24 & $101 \pm 20^{\mathrm{aA}}$ & $102 \pm 14^{\mathrm{aA}}$ & $88 \pm 8^{\mathrm{abcdeA}}$ & $95 \pm 11^{\mathrm{aA}}$ & $100 \pm 18^{\mathrm{abcdA}}$ & $93 \pm 6^{\mathrm{aA}}$ \\
\hline 25 & $120 \pm 19^{\mathrm{aA}}$ & $102 \pm 16^{\mathrm{aA}}$ & $96 \pm 12^{\mathrm{abcA}}$ & $97 \pm 29^{\mathrm{aA}}$ & $98 \pm 14^{\mathrm{abcdA}}$ & $88 \pm 6^{\mathrm{aA}}$ \\
\hline 26 & $98 \pm 16^{\mathrm{aA}}$ & $95 \pm 8^{\mathrm{aA}}$ & $93 \pm 11^{\mathrm{abcA}}$ & $105 \pm 16^{\mathrm{aA}}$ & $98 \pm 16^{\mathrm{abcdA}}$ & $95 \pm 10^{\mathrm{aA}}$ \\
\hline 27 & $84 \pm 10^{\mathrm{aA}}$ & $101 \pm 13^{\mathrm{aA}}$ & $78 \pm 9^{\text {bcdefA }}$ & $77 \pm 10^{\mathrm{aA}}$ & $81 \pm 11^{\mathrm{abcdA}}$ & $99 \pm 17^{\mathrm{aA}}$ \\
\hline 28 & $94 \pm 12^{\mathrm{aA}}$ & $89 \pm 15^{\mathrm{aA}}$ & $85 \pm 5^{\text {abcdeA }}$ & $85 \pm 16^{\mathrm{aA}}$ & $92 \pm 16^{\mathrm{abcdA}}$ & $96 \pm 15^{\mathrm{aA}}$ \\
\hline
\end{tabular}

Values expressed mean \pm standard deviation. Means followed by different lowercase letters in a column and capital letters on the lines differ by the Tukey test $(p<0.05)$

tanks affected food utilization, larval development, larval condition, survival, and productivity. Guo et al. (2012) reported that periodic variation of the spectrum from blue to green light promoted the growth of Litopenaeus vannamei and thus recommended periodic fluctuations of colored light in the regulation of bright light for the cultivation of this species. In contrast, we found that the violet color is the one with the lowest luminescence and have similar results to white, while yellow had results close to those of the red color. Maciel and Valenti (2014) also observed similar results in the red tank for the cultivation of M. amazonicum.

Feeding M. amazonicum larvae with A. salina was standardized in all treatments used in the present study, following previous recommendations (Moraes-Valenti and Valenti 2010; Araújo and Valenti 2011), for optimization. The color of live food offered to shrimp larvae has an essential effect on the visual perception of food, since the contrast between the color of the food and tank increases larval capture efficiency, therefore affecting their survival and growth (Maciel and Valenti 2014). The data obtained here demonstrate the importance of light color in the tanks for feeding M. amazonicum larvae. Thus, the higher survival rates of M. amazonicum larvae in the tanks under white light might be related to the distribution of food in the water column and the amount of energy carried by light. A reduction in the available energy for metabolism and an increase of agonistic behavior and stress may reduce M. amazonicum larval 
Table 3 Larval stage index (LSI) of Macrobrachium amazonicum exposed to different light colors for $12 \mathrm{~h} \mathrm{day}^{-1}$ during 28 days of larviculture

\begin{tabular}{|c|c|c|c|c|c|c|}
\hline \multirow[t]{2}{*}{ Days } & \multicolumn{6}{|c|}{ Light color of tanks } \\
\hline & Blue & Green & Red & Violet & Yellow & White \\
\hline 2 & $2.3 \pm 0.4^{\mathrm{a}}$ & $2.3 \pm 0.4^{\mathrm{a}}$ & $1.3 \pm 0.4^{\mathrm{a}}$ & $2.3 \pm 0.4^{\mathrm{a}}$ & $2.0 \pm 0.0^{\mathrm{a}}$ & $2.3 \pm 0.4^{\mathrm{a}}$ \\
\hline 4 & $3.0 \pm 0.0^{\mathrm{a}}$ & $2.8 \pm 0.4^{\mathrm{a}}$ & $2.0 \pm 0.0^{\mathrm{b}}$ & $3.0 \pm 0.0^{\mathrm{a}}$ & $2.5 \pm 0.5^{\mathrm{ab}}$ & $3.0 \pm 0.0^{\mathrm{a}}$ \\
\hline 6 & $3.5 \pm 0.5^{\mathrm{ab}}$ & $3.3 \pm 0.4^{\mathrm{ab}}$ & $2.5 \pm 0.5^{b}$ & $3.5 \pm 0.5^{\mathrm{ab}}$ & $2.8 \pm 0.4^{\mathrm{ab}}$ & $3.8 \pm 0.4^{\mathrm{a}}$ \\
\hline 8 & $4.3 \pm 0.4^{\mathrm{ab}}$ & $3.8 \pm 0.4^{\mathrm{ab}}$ & $3.3 \pm 0.4^{b}$ & $4.5 \pm 0.5^{\mathrm{a}}$ & $3.8 \pm 0.4^{\mathrm{ab}}$ & $4.5 \pm 0.5^{\mathrm{a}}$ \\
\hline 10 & $4.8 \pm 0.4^{\mathrm{ab}}$ & $4.0 \pm 0.0^{\mathrm{ab}}$ & $3.8 \pm 0.4^{\mathrm{b}}$ & $5.0 \pm 0.7^{\mathrm{ab}}$ & $4.5 \pm 0.5^{\mathrm{ab}}$ & $5.3 \pm 0.4^{\mathrm{a}}$ \\
\hline 12 & $5.3 \pm 0.4^{\mathrm{abc}}$ & $4.5 \pm 0.5^{\mathrm{c}}$ & $4.3 \pm 0.4^{\mathrm{c}}$ & $5.8 \pm 0.4^{\mathrm{ab}}$ & $4.8 \pm 0.4^{b c}$ & $6.0 \pm 0.0^{\mathrm{a}}$ \\
\hline 14 & $5.8 \pm 0.4^{\mathrm{abc}}$ & $5.0 \pm 0.0^{\mathrm{bc}}$ & $4.8 \pm 0.4^{\mathrm{c}}$ & $6.0 \pm 0.7^{\mathrm{ab}}$ & $5.8 \pm 0.4^{\mathrm{abc}}$ & $6.5 \pm 0.5^{\mathrm{a}}$ \\
\hline 16 & $6.5 \pm 0.5^{\mathrm{ab}}$ & $6.0 \pm 0.0^{\mathrm{bc}}$ & $5.3 \pm 0.4^{\mathrm{c}}$ & $6.8 \pm 0.4^{\mathrm{ab}}$ & $6.3 \pm 0.4^{\mathrm{abc}}$ & $7.3 \pm 0.4^{\mathrm{a}}$ \\
\hline 18 & $7.3 \pm 0.4^{\mathrm{a}}$ & $6.8 \pm 0.4^{\mathrm{ab}}$ & $5.8 \pm 0.4^{b}$ & $7.3 \pm 0.4^{\mathrm{a}}$ & $6.5 \pm 0.5^{\mathrm{ab}}$ & $7.5 \pm 0.5^{\mathrm{a}}$ \\
\hline 20 & $7.5 \pm 0.5^{\mathrm{ab}}$ & $7.0 \pm 0.0^{\mathrm{b}}$ & $6.8 \pm 0.4^{b}$ & $7.8 \pm 0.4^{\mathrm{ab}}$ & $7.5 \pm 0.5^{\mathrm{ab}}$ & $8.5 \pm 0.5^{\mathrm{a}}$ \\
\hline 22 & $8.3 \pm 0.4^{\mathrm{ab}}$ & $7.8 \pm 0.4^{\mathrm{ab}}$ & $7.3 \pm 0.4^{b}$ & $8.5 \pm 0.5^{\mathrm{a}}$ & $7.8 \pm 0.4^{\mathrm{ab}}$ & $8.8 \pm 0.4^{\mathrm{a}}$ \\
\hline 24 & $8.8 \pm 0.4^{\mathrm{abc}}$ & $8.3 \pm 0.4^{b c}$ & $7.8 \pm 0.4^{\mathrm{c}}$ & $9.3 \pm 0.4^{\mathrm{ab}}$ & $8.5 \pm 0.5^{b c}$ & $9.8 \pm 0.4^{\mathrm{a}}$ \\
\hline 26 & $9.5 \pm 0.5^{\mathrm{abc}}$ & $9.0 \pm 0.0^{\mathrm{bc}}$ & $8.5 \pm 0.5^{\mathrm{c}}$ & $9.8 \pm 0.4^{\mathrm{ab}}$ & $9.0 \pm 0.0^{\mathrm{bc}}$ & $10.5 \pm 0.5^{\mathrm{a}}$ \\
\hline 28 & $10.0 \pm 0.7^{\mathrm{abc}}$ & $9.3 \pm 0.4^{b c}$ & $8.8 \pm 0.4^{\mathrm{c}}$ & $10.5 \pm 0.5^{\mathrm{ab}}$ & $9.5 \pm 0.5^{\mathrm{abc}}$ & $10.8 \pm 0.4^{\mathrm{a}}$ \\
\hline
\end{tabular}

Values expressed by mean \pm standard deviation. Means followed by different lowercase letters in a column and capital letters on the lines differ significant by the Tukey test $(p<0.05)$

survival in tanks maintained under red light. Nevertheless, stress could be a factor related to the survival reduction of $M$. amazonicum larvae in red light.

Artemia salina nauplii appear orange, since, in white light, they absorb the remaining wave frequencies, reflecting only the orange. Nevertheless, this nauplii coloration presents diverse spectra under different colors of light. Due to the natural pigmentation of nauplii, they seem darker under red or green light. Another characteristic of red light is the higher refractive index than other primary colors, which is easily diverted or absorbed in water (Bohren et al. 2007; Halliday and Resnick 2015). In the present study, these factors represent a difficulty in capturing A. salina nauplii by M. amazonicum larvae in tanks under red light, since that light is reflected. Thus, in tanks under dark light, nauplii capture by M. amazonicum larvae was hindered as the main mechanism to

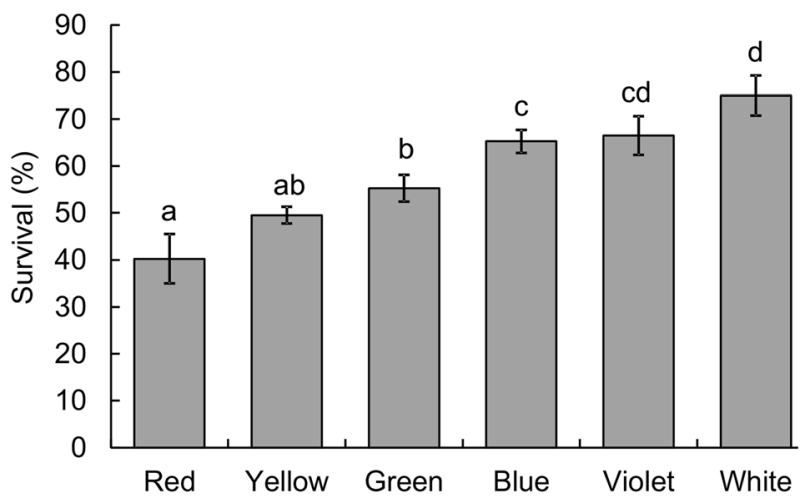

Fig. 2 Survival of larvae and post-larvae of Macrobrachium amazonicum in 28 days of cultivation in tanks under light with different colors for $12 \mathrm{~h} \mathrm{day}^{-1}$. Values expressed by mean \pm standard deviation. Different letters indicate significant difference by the Tukey test $(p<0.01)$ 
locate prey was visual (Valenti et al. 2010;Araújo and Valenti 2011; Maciel and Valenti 2014). Therefore, in aquaculture of $M$. amazonicum, the light color may affect the feeding rate and, consequently, the production and productivity.

For M. amazonicum larvae cultivated in tanks of different colors, Maciel and Valenti (2014) observed a higher consumption of live food in tanks under green and red light. However, in this study, the light was reflected from the colored walls of the tanks, but light radiation penetrating the tank may not be the same wavelength corresponding to the tank color. Nevertheless, since white light comprises all colors of the visible spectrum (Bohren et al. 2007), the best contrast occurred when M. amazonicum larvae were cultured in tanks under white light, which penetrated the whole tank with constant intensity. Thus, the differences in the results of these studies might be related to light dispersion or the tank dimensions.

The M. amazonicum larval cycle is relatively short, lasting approximately 20 days, with an interval of 1-2 days between the different morphological larval stages (Hayd et al. 2008; Maciel and Valenti 2014). However, the duration of the M. amazonicum larval cycle may vary depending on the quantity and quality of food offered, luminosity, water temperature, and other water quality variables. Nevertheless, in the present study, no difference was observed in the duration of the larval cycle. Similar results were described for M. amazonicum larvae cultured in tanks of different colors (Maciel and Valenti 2014). However, our results indicated a delay in the development of initial M. amazonicum larval stages under red light than that under white light. Consequently, the delay in the development of stages occurred during the entire trial, leading to a delay of four days to the final M. amazonicum larval stage under red light.

In summary, increasing the frequency of colored light used in tanks in the larviculture of M. amazonicum increased the temperature, $\mathrm{pH}$, and dissolved oxygen in water, in addition to illuminating live food more clearly, reducing period larval development, and increasing the larval condition index, survival, and productivity. It is possible that M. amazonicum larvae have functional eyes from their first larval stage and adapted visually to a bright environment. This visual acuity plays an important role in the positioning and capture of prey. Lighting tanks with dark colors, i.e., red, made it difficult to see the prey. Therefore, our results suggest that the ideal color for illuminating tanks in larviculture of M. amazonicum is the white.

Acknowledgments The authors thanks to Elane Tavares Lobo, Evandro Freitas dos Santos, Osiel Amoras de Araújo junior, Sting Silva Duarte, and Tainá Martins de Carvalho for their help in this study.

Funding information This work was supported by the Fundação de Amparo à Pesquisa do Estado do Amapá/ FAPEAP, Brazil (\#250.203/058/2014) and by the Conselho Nacional de Desenvolvimento Científico e Tecnológico - CNPq (\# 444367/2014-4). Tavares-Dias M. was granted a Research Productivity fellowship (\# 303013/2015-0) from the Conselho Nacional de Pesquisa e Desenvolvimento Tecnológico (CNPq, Brazil).

\section{Compliance with ethical standards}

Conflict of interest The authors declare that they have no conflict of interest.

Ethical disclosures This study was conducted following the principles adopted by the Brazilian College of Animal Experimentation (COBEA). 


\section{References}

Araújo MC, Valenti WC (2011) Efeito da intensidade luminosa no desenvolvimento larval do camarão-daamazônia, Macrobrachium amazonicum. Bol Inst Pesca 37:155-164

Bohren CF, Clothiaux EE, Johnson ND (2007) Fundamentals of atmospheric radiation. Am J Phys 75:671-672. https://doi.org/10.1119/1.2733693

Cronin TW, Bok MJ, Lin C (2017) Crustacean larvae-vision in the plankton. Integr Comp Biol 57:1139-1150. https://doi.org/10.1093/icb/icx007

Giri SS, Sahoo SK, Sahu BB, Sahu AK, Mohanty SN, Mukhopadhyay PK, Ayyappan S (2002) Larval survival and growth in Wallago attu (Bloch and Schneider): effects of light, photoperiod and feeding regimes. Aquaculture 213:151-161. https://doi.org/10.1016/S0044-8486(02)00012-1

Guo B, Wang F, Dong S, Gao Q (2011) The effect of rhythmic light color fluctuation on the molting and growth of Litopenaeus vannamei. Aquaculture 314:210-214. https://doi.org/10.1016/j. aquaculture.2011.02.023

Guo B, Wang F, Li Y, Dong S (2012) Effect of periodic light color change on the molting frequency and growth of Litopenaeus vannamei. Aquaculture 362-363:67-71. https://doi.org/10.1016/j.aquaculture.2012.07.034

Guo B, Wang F, Li Y, Dong S (2013) Effect of periodic light intensity change on the molting frequency and growth of Litopenaeus vannamei. Aquaculture 396-399:66-70. https://doi.org/10.1016/j. aquaculture.2013.02.033

Halliday R, Resnick D (2015) Fundamental of physics, 10th edn. Wiley, New York

Hayd AL, Anger K, Valenti WC (2008) The moulting cycle of larval Amazon river prawn Macrobrachium amazonicum reared in the laboratory. Nauplius 16:55-63

Hoang T, Barchiesis M, Lee SY, Keenan CP, Marsden GE (2003) Influences of light intensity and photoperiod on moulting and growth of Penaeus merguiensis cultured under laboratory conditions. Aquaculture 216:343354. https://doi.org/10.1016/S0044-8486(02)00460-X

Jaski MG, Kamrani E, Salarzadeh A (2014) The study effect of sun light on growth performance and survival of postlarval white leg shrimp (Litopenaeus vannamei) and salinity stress resistance. Eur J Exp Biol 4(2):7-12

Kawamura G, Bagarinao TU, Yong ASK, Faisal AB, Lim LS (2018) Limit of colour vision in dim light in larvae of the giant freshwater prawn Macrobrachium rosenbergii. Fish Sci 84:365-371. https://doi.org/10.1007 /s12562-018-1179-4

Lima JF, Santos TS (2014) Aspectos econômicos e higiênico-sanitários da comercialização de camarões de água doce em feiras livres de Macapá e Santana, Estado do Amapá. Biota Amaz 4:1-8. https://doi.org/10.18561 /2179-5746/biotaamazonia.v4n1p1-8

Maciel CR, Valenti WC (2009) Biology, fisheries, and aquaculture of the Amazon River prawn Macrobrachium amazonicum: a review. Nauplius 17:61-79

Maciel CR, Valenti WC (2014) Effect of tank colour on larval performance of the Amazon River prawn Macrobrachium amazonicum. Aquac Res 45:1041-1050. https://doi.org/10.1111/are.12048

Manzi JJ, Maddox MB, Sandifer PA (1977) Algal supplement enhancement of Macrobrachium rosenbergii (De Man) larviculture. Proc World Maricult Soc 8:207-223. https://doi.org/10.1111/j.1749-7345.1977.tb00119.x

Matsuda K, Wilder MN (2014) Eye structure and function in the giant freshwater prawn Macrobrachium rosenbergii. Fish Sci 80:531-541

Meyer-Rochow VB (2001) The crustacean eye: dark/light adaptation, polarization sensitivity, flicker fusion frequency, and photoreceptor damage. Zool Sci 18:1175-1197

Moraes-Valenti P, Valenti WC (2010) Culture of the Amazon river prawn Macrobrachium amazonicum. In: New MB, Valenti WC, Tidwell JH, D’Abramo LR, Kutty MN (eds). Freshwater prawns: biology and farming, Wiley-Blackwell, Oxford, pp. 485-501

R Core Team (2015) R A Lang. Environ. Stat. Comput. R Found. Stat. Comput. Vienna, Austria. ISBN 3900051-07-0, URL http://www.r-project.org/. Accessed 18 Feb 2019

Scarinci AL, Marineli F (2014) O modelo ondulatório da luz como ferramenta para explicar as causas da cor. Rev Bras Ensino Física 36:1-14

Tayamen M, Brown JH (1999) A condition index for evaluating larval quality of Macrobrachium rosenbergii (De Man, 1879). Aquac Res 30:917-922

Utne-Palm AC, Breen M, Løkkeborg S, Humborstad OB (2018) Behavioural responses of krill and cod to artificial light in laboratory experiments. PLoS One 13:e0190918. https://doi.org/10.1371/journal. pone.0190918 
Valenti WC, Daniels WH, New MB, Correia ES (2010) Hatchery systems and management. In: New MB, Valenti WC, Tidwell JH, D’Abramo LR, Kutty MN (eds) Freshwater prawns biology and farming. Blackwell Publishing, Ames, pp 55-85

You K, Yang H, Liu Y, Liu S, Zhou Y, Zhang T (2006) Effects of different light sources and illumination methods on growth and body color of shrimp Litopenaeus vannamei. Aquaculture 252:557-565. https://oi. org/10.1016/j.aquaculture.2005.06.041

Zar JH (2010) Biostatistical Analysis. Prentice Hall, New Jersey

Zhang P, Zhang X, Li J, Huang G (2006) The effects of body weight, temperature, salinity, pH, light intensity and feeding condition on lethal DO levels of white leg shrimp, Litopenaeus vannamei (Boone, 1931). Aquaculture, 256(1-4): 579-587. https://doi.org/10.1016/j.aquaculture.2006.02.020

Publisher's note Springer Nature remains neutral with regard to jurisdictional claims in published maps and institutional affiliations. 